\title{
Opposing Effects of Membrane-Anchored CX3CL1 on Amyloid and Tau Pathologies via the p38 MAPK Pathway
}

\author{
Sungho Lee, ${ }^{1,3}$ Guixiang Xu, ${ }^{1}$ Taylor R. Jay, ${ }^{1,3}$ Sabina Bhatta, ${ }^{1}{ }^{\circledR}$ Ki-Wook Kim, ${ }^{4}$ Steffen Jung, ${ }^{4}$ Gary E. Landreth, ${ }^{3}$ \\ Richard M. Ransohoff, ${ }^{1}$ and Bruce T. Lamb ${ }^{1,2,3}$ \\ ${ }^{1}$ Department of Neurosciences, Lerner Research Institute, Cleveland Clinic, Cleveland, Ohio 44195, ${ }^{2}$ Department of Genetics and ${ }^{3}$ Department of \\ Neurosciences, Case Western Reserve University School of Medicine, Cleveland, Ohio 44106, and ${ }^{4}$ Department of Immunology, Weizmann Institute of \\ Science, Rehovot 7610001, Israel
}

Several Alzheimer's disease (AD) risk genes are specifically expressed by microglia within the CNS. However, the mechanisms by which microglia regulate the pathological hallmarks of $\mathrm{AD}$ - extracellular deposition of $\beta$-amyloid $(\mathrm{A} \beta)$ and intraneuronal hyperphosphorylation of microtubule-associated protein tau (MAPT) - remain to be established. Notably, deficiency for the microglial CX3CR1 receptor has opposing effects on $\mathrm{A} \beta$ and MAPT pathologies. CX3CL1, the neuronally derived cognate ligand for CX3CR1, signals both in membrane-anchored and soluble forms. In this study, we sought to determine the relative contribution on membrane-anchored versus soluble CX3CL1 in regulating the microglia-mediated amelioration of $A \beta$ pathology, as well as provide insight into the potential downstream microglial-based mechanisms. As expected, CX3CL1 deficiency reduced A $\beta$ deposition in APPPS1 animals in a similar manner to CX3CR1 deficiency. Surprisingly, however, CX3CL1-deficient APPPS1 animals exhibited enhanced neuronal MAPT phosphorylation despite reduced amyloid burden. Importantly, neither of these phenotypes was altered by transgenic expression of the soluble CX3CL1 isoform, suggesting that it is the membrane-anchored version of CX3CL1 that regulates microglial phagocytosis of $A \beta$ and neuronal MAPT phosphorylation. Analysis of transcript levels in purified microglia isolated from APPPS1 mice with the various CX3CL1/CX3CR1 genotypes revealed increased expression of inflammatory cytokines and phagocytic markers, which was associated with activation of p38 mitogen-activated protein kinase and $\mathrm{A} \beta$ internalization within microglia. Together, these studies challenge the "frustrated phagocytosis" concept and suggest that neuronal-microglial communication link the two central AD pathologies.

Key words: Alzheimer's disease; CX3CL1; microglia; phagocytosis

\section{Introduction}

Alzheimer's disease $(\mathrm{AD})$ is characterized by extracellular accumulation of $\beta$-amyloid $(\mathrm{A} \beta)$ peptides in senile plaques and intraneuronal aggregates of hyperphosphorylated microtubule associated protein tau (MAPT) in neurofibrillary tangles. In addition, accumulating evidence suggest that microglia-mediated neuroinflammatory processes directly contribute to AD pathogenesis. This is highlighted by the recent identification of several $\mathrm{AD}$ risk genes that are specifically expressed by microglia within the CNS, including CD33, CR1, and TREM2 (Lambert et al., 2009; Hollingworth et al., 2011; Naj et al., 2011; Guerreiro et al.,

\footnotetext{
Received March 3, 2014; revised July 13, 2014; accepted Aug. 4, 2014.

Author contributions: S.L. and B.T.L. designed research; S.L., X.G., T.R.J., and S.B. performed research; K.-W.K., S.J., G.E.L., and R.M.R. contributed unpublished reagents/analytic tools; S.L. analyzed data; S.L., T.R.J., R.M.R., and B.T.L. wrote the paper.

This work was supported by an Alzheimer's Association Multi-Center Program grant to B.T.L., G.E.L. and R.M.R.; National Institute on Aging Grant AG023012 to B.T.L.; National Institute of Neurological Disorders and Stroke Grant NS047804 to B.T.L. and R.M.R.; National Multiple Sclerosis Society Research Grant 4550 to R.M.R.; National Research Service Award Fellowship F30 NS068003 to S.L.; and National Research Service Award T32 GM007250 to S.L. and NS067431 to T.R.J.

The authors declare no competing financial interests.

Correspondence should be addressed to Bruce T. Lamb, Department of Neurosciences, Cleveland Clinic, 9500 Euclid Blvd., NC30, Cleveland, OH 44195. E-mail: lambb@ccf.org.

DOI:10.1523/JNEUROSCI.0853-14.2014

Copyright $\odot 2014$ the authors $\quad 0270-6474 / 14 / 3412538-09 \$ 15.00 / 0$
}

2013; Jonsson et al., 2013). However, the exact role microglia and neuroinflammation more generally play in regulating both $\mathrm{A} \beta$ and MAPT pathology remains to be clearly established. Notably, several recent studies from our groups and others suggest that neuron-microglia signaling via the chemokine fractalkine (CX3CL1) and its cognate receptor CX3CR1 plays a unique role in $\mathrm{AD}$ pathogenesis.

In the CNS, CX3CL1 is exclusively expressed by neurons and CX3CR1 is exclusively expressed by microglia (Cardona et al., 2006; Kim et al., 2011). CX3CL1 can signal to CX3CR1 either as a membrane-anchored entity or as a soluble chemokine upon a disintegrin and metalloproteinase domain-containing protein 10 (ADAM10)-mediated or ADAM17-mediated cleavage (Garton et al., 2001; Hundhausen et al., 2003). In several transgenic mouse models of $\mathrm{AD}, \mathrm{CX} 3 \mathrm{CR} 1$ deficiency ameliorated $\mathrm{A} \beta$ deposition by altering microglial activation and promoting microglial phagocytosis (Lee et al., 2010; Liu et al., 2010). On the other hand, CX3CR1 deficiency exacerbated microglial activation and increased MAPT phosphorylation via neuronal p38 mitogenactivated protein kinase (MAPK) activation in the hTau model of tauopathy (Bhaskar et al., 2010). While these data have suggested an important role for CX3CL1-CX3CR1 interaction in modulating $\mathrm{AD}$-related pathologies, the detailed molecular mechanisms underlying the divergent $\mathrm{A} \beta$ and MAPT phenotypes, as well as 
the relative contribution of membrane-anchored versus soluble CX3CL1 entities, remain to be defined.

To examine the isoform-dependent effects of CX3CL1 signaling on the development of $\mathrm{AD}$ pathologies, we used CX3CL1deficient mice that express a transgene encoding an obligate soluble CX3CL1 (SolTg). Consistent with previous results in CX3CR1-deficient APPPS1 animals (Lee et al., 2010), CX3CL1deficient APPPS1 mice also exhibited reduced $\mathrm{A} \beta$ deposition compared with APPPS1 controls. Unexpectedly, however, CX3CL1deficient APPPS1 mice demonstrated elevated phospho-MAPT levels despite reduced amyloid burden. Intriguingly, SolTg expression did not additionally affect pathology, suggesting that membraneanchored CX3CL1 is solely responsible for the observed effects.

To determine the mechanisms underlying the opposing effects of membrane-anchored CX3CL1 deficiency on the development of $\mathrm{A} \beta$ and MAPT pathologies in APPPS1 animals, we examined isolated microglia for alterations in transcript levels of AD-relevant genes and found increased interleukin $1 \alpha$ (IL1 $\alpha)$, interleukin 6 (IL6), and macrophage scavenger receptor 1 (MSR1, also known as SRA) expression in the absence of membrane-anchored CX3CL1. Furthermore, these alterations were associated with increased $\mathrm{p} 38$ MAPK activation within microglia and enhanced A $\beta$ phagocytosis. Together, our results suggest that membrane-anchored CX3CL1 has opposing effects on $\mathrm{A} \beta$ and MAPT pathologies through alterations in microglial functioning.

\section{Materials and Methods}

Mice. The APPPS1-21 (APPPS1; RRID: MGI_3765351) mouse line coexpresses the APP K670M/N671L and PS1 L166P familial AD mutations under the control of the neuron-specific Thyl promoter (Radde et al., 2006). Generation of a mouse line exclusively expressing soluble CX3CL1, by introducing bacterial artificial chromosome (BAC) transgene encoding truncated CX3CL1 (SolTg) to $\mathrm{C}_{3} \mathrm{cll}^{-1-}$ mice (RRID: MGI_2388041), has been described previously (Kim et al., 2011). For the current study, APPPS1 mice (kindly provided by Mathias Jucker) were mated to ${\mathrm{C} x 3 \mathrm{Cl}^{-1-}}^{-1}$;olTg animals (kindly provided by Steffen Jung) and subsequently intercrossed to generate APPPS $1 ; C \times 3 \mathrm{Cll}^{-/-}$and APPPS1; $\mathrm{C} 3 \mathrm{Cll}^{-1-} ;$ SolTg genotypes. In addition, APPPS1 mice were mated to $\mathrm{C} \times 3 \mathrm{crl}^{-1-}$ animals (RRID: MGI_2670351) and subsequently intercrossed to generate the APPPS1;CX3cr ${ }^{-1-}$ genotype, as described previously (Lee et al., 2010). Age-matched APPPS1 animals were used as controls. All strains were maintained on the C57BL/6J background. Animals of either sex were used for this study. They were housed at the Cleveland Clinic Biological Resources Unit, a facility fully accredited by the Association of Assessment and Accreditation of Laboratory Animal Care. All experimental procedures were approved by the Institutional Animal Care and Use Committee of the Cleveland Clinic.

Histology. Mice were deeply anesthetized with Avertin and perfused intracardially with ice-cold PBS. The brain was immediately removed from the cranium, transferred to $4 \%$ paraformaldehyde in PBS overnight at $4^{\circ} \mathrm{C}$, and cryoprotected in $30 \%$ sucrose in PBS thereafter. After bisecting across the midline, the brains were embedded in optimal cutting temperature compound, and $30 \mu \mathrm{m}$ sagittal, free-floating sections were cut and stored in PBS at $4^{\circ} \mathrm{C}$ until use.

Thioflavine $S$ staining and quantification. Sections were mounted onto SuperPlus glass slides and air-dried. Sections were subsequently immersed in $1 \%$ thioflavine $S$ in distilled water for 5 min, destained in $70 \%$ ethanol for $5 \mathrm{~min}$, and washed twice in PBS. The slides were coverslipped with Vectashield mounting media (Vector) and edges were sealed with nail polish.

A series of low-power, overlapping images of thioflavine S-stained sections were compiled to form an integrated view of the entire cortex and hippocampus. The number of thioflavine S-positive plaques was quantified in the cortex (below the pial surface and above the corpus callosum) and the hippocampus (excluding the subiculum and fimbria) from three separate sections per mouse. All data were expressed as number of thioflavine S-positive plaques per $\mathrm{mm}^{2} \pm$ SEM. Statistically significant alterations between the genotypes were determined by one-way ANOVA followed by Newman-Keuls post hoc test (GraphPad Prism; RRID: nlx_152166).

Immunohistochemistry. Sections were rinsed with PBS containing $0.1 \%$ Triton X-100 (PBST), pretreated with $10 \mathrm{mmol} / \mathrm{L}$ sodium citrate buffer, $\mathrm{pH} 6.0(0.05 \%$ Triton $\mathrm{X}-100)$, for $30 \mathrm{~min}$ at $85^{\circ} \mathrm{C}$ for antigen retrieval, cooled for $30 \mathrm{~min}$ at room temperature, and blocked for $1 \mathrm{~h}$ at room temperature in PBS containing 5\% normal goat serum and $0.3 \%$ Triton X-100. After overnight incubation at $4^{\circ} \mathrm{C}$ with primary antibodies diluted in blocking buffer, sections were washed three times in PBST and incubated for $1 \mathrm{~h}$ at room temperature in blocking buffer containing secondary antibodies conjugated to fluorescent Alexa dyes (1:1000; Invitrogen; catalog \#A21121, \#A21242, \#A11034, \#A11030, \#A11081, and \#A21236; RRIDs: AB_10053811, AB_1500900, AB_10562715, $A B \_144695, A B \_141738$, and $\left.A B \_141725\right)$. The sections were finally washed three times in PBST, mounted onto SuperPlus glass slides, and coverslipped with hard-set Vectashield mounting media.

The primary antibodies used in the study included the following: anti-A $\beta$ mouse monoclonal antibody 4G8 (1:250; Signet Laboratories, catalog \#SIG-39200-1000; RRID: AB_662819), anti-phospho-p38 MAPK rabbit polyclonal antibody (1:100; Cell Signaling Technology, catalog \#9211L; RRID: AB_331641), anti-CD45 rat polyclonal antibody (1:250; Serotec, catalog \#MCA1388; RRID: AB_321729), anti-phosphoMAPT mouse monoclonal antibody AT8 (1:250; Pierce, catalog \#MN1020; RRID: AB_223647), and anti-Iba1 rabbit polyclonal antibody (1:1000; Wako, catalog \#019-19741; RRID: AB_839504). For colabeling of 4G8 and AT8, isotype-specific anti-mouse secondary antibodies were used. For phospho-p38 MAPK labeling, sections were incubated with the primary antibody at $4^{\circ} \mathrm{C}$ for $72 \mathrm{~h}$, followed by $2 \mathrm{~h}$ at room temperature.

Quantification of $A \beta$ phagocytosis. Confocal $Z$-stacks $10 \mu \mathrm{m}$ in depth were collected at $40 \times$ magnification with $1 \mu \mathrm{m}$ between each slice, and images were postprocessed using ImageJ (National Institutes of Health; RRID: nif-0000-30467). Random plaque-containing areas of cortex were imaged using standardized parameters of laser intensity, gain, and pinhole size. To determine $\mathrm{A} \beta$ phagocytosis, each distinct, $4 \mathrm{G} 8$-positive particle that was completely internalized by all Iba1-positive, plaqueadjacent microglia within a given confocal slice was outlined from images autocorrected for brightness and contrast. Intracellular $A \beta$ volume was then determined by multiplying the areas of these outlined regions by the distance between each slice and summing the results across all confocal slices within the $Z$-stack. At least 37 plaque-adjacent microglia from each mouse were analyzed in this fashion. Animal number per genotype was four. All results were expressed as average $\mathrm{A} \beta$ volume per cell \pm SEM and compared between genotypes using one-way ANOVA with NewmanKeuls post hoc test.

ELISA and Western blot. Mice were deeply anesthetized and killed by intracardial perfusion. Their cortices were rapidly dissected, snap frozen in dry ice, and stored at $-80^{\circ} \mathrm{C}$ until use. For ELISA, each hemicortex was homogenized in $500 \mu \mathrm{l}$ of buffer containing $150 \mathrm{mmol} / \mathrm{L} \mathrm{NaCl}, 0.01$ $\mathrm{mol} / \mathrm{L}$ Tris, $1.0 \mathrm{mmol} / \mathrm{L}$ EDTA with 1:100 dilution of protease inhibitor mixture (Sigma-Aldrich) and centrifuged at 10,000 rpm for $30 \mathrm{~min}$ at $4^{\circ} \mathrm{C}$. The concentration of soluble CX3CL1 was measured from the supernatant using a commercially available ELISA kit (DuoSet, R\&D Systems) and compared with a standard curve of recombinant CX3CL1. Results were reported as picograms of CX3CL1 per milligram of wet brain \pm SEM.

For Western blots, each hemicortex was homogenized in 10 volumes of T-PER reagent (Thermo Scientific) containing 1:100 dilutions of a protease inhibitor mixture and a phosphatase inhibitor mixture (SigmaAldrich). Homogenates were subsequently sonicated to shear DNA and centrifuged to remove nuclei and cellular debris. Total protein concentration was determined using the BCA Protein Assay Kit (Thermo Scientific). Twenty-five micrograms of brain protein were run on a gradient Novex NuPage 4-12\% Bis-Tris gel (Invitrogen) and transferred to PVDF membranes. The resulting Western blots were blocked with $5 \%$ milk in PBS and incubated with the following: AT8 antibody (1:2000), Tau5 antibody raised against total MAPT (mouse monoclonal; 1:20,000; Invit- 
rogen, catalog \#AHB0042; RRID: AB_1502093), phospho-p38 MAPK antibody (rabbit polyclonal; 1:1000; Invitrogen, catalog \#368500; RRID: AB_10104365), total p38 MAPK antibody (rabbit polyclonal; 1:10,000; Cell Signaling Technology, catalog \#9212L; RRID: AB_823589), phospho-MAPKAPK2 antibody (rabbit polyclonal; 1:1000; Cell Signaling Technology, catalog \#3041L; RRID: AB_330726), or $\beta$-actin antibody (mouse monoclonal; 1:20,000 or 1:200,000; Sigma-Aldrich, catalog \#A5316; RRID: AB_476743) diluted in 5\% milk in PBS containing $0.1 \%$ Tween 20 . After overnight incubation at $4^{\circ} \mathrm{C}$ with the primary antibodies, blots were washed with PBST, incubated with anti-mouse or anti-rabbit secondary antibodies conjugated to horseradish peroxidase $(1: 10,000$; Jackson Laboratories; catalog \#715-035-151 and \#711-035-152; RRIDs: unavailable and AB_10015282) for $1 \mathrm{~h}$ at room temperature, and developed with the enhanced chemiluminescence substrate (PerkinElmer). Immunoreactive band densities were quantified using the Gel Analyzer tool in ImageJ (National Institutes of Health). The integrated density ratios for AT8/Tau5, phospho-p38 MAPK/total p38 MAPK, and phospho-MK2/ $\beta$-actin were calculated, and mean \pm SEM was used to determine genotype-dependent alterations using an unpaired $t$ test or ANOVA followed by Newman-Keuls post hoc test.

Isolation of microglia. Mice were perfused intracardially using HBSS without $\mathrm{Ca}^{2+}$ or $\mathrm{Mg}^{2+}$. Brains were removed from the cranium, homogenized in $10 \mathrm{ml}$ of digestion buffer [HBSS containing $0.05 \%$ collagenase $\mathrm{D}$ (Roche), $0.1 \mu \mathrm{g} / \mathrm{ml}$ 7-amino-1-chloro-3-tosylamido-2-heptanone (TLCK; Sigma-Aldrich), 0.025 U/ml DNase I (Sigma-Aldrich), $0.25 \%$ dispase (Roche), and $10 \mathrm{mmol} / \mathrm{L}$ HEPES (Invitrogen )], mixed for $15 \mathrm{~min}$ at room temperature, centrifuged, washed, and resuspended in $10 \mathrm{ml}$ of $30 \%$ isotonic Percoll (GE Healthcare). This cell suspension was subsequently overlaid on $2 \mathrm{ml}$ of $70 \%$ isotonic Percoll and centrifuged without break for $30 \mathrm{~min}$ at $800 \mathrm{~g}$. The cells from the resulting 70:30\% interface, consisting of $70-80 \%$ microglia (data not shown), were collected and washed. Microglial pellets were then used for flow cytometry or RNA extraction.

Flow cytometry. Isolated microglial cells were resuspended in PBS containing $1 \% \mathrm{BSA}$ and $0.1 \% \mathrm{NaN}_{3}$, incubated for $5 \mathrm{~min}$ at room temperature with the CD16/CD32 antibody (rat monoclonal; 1:200; BD PharMingen, catalog \#553141; RRID: AB_394656) to block Fc receptors, and then incubated for $30 \mathrm{~min}$ on ice with PerCP-conjugated CD11b (rat monoclonal; 1:100; BioLegend, catalog \#101230; RRID: AB_2129374) and unconjugated CX3CR1 antibodies (rabbit polyclonal; 1:100; Abcam, catalog \#ab8021; RRID: AB_306203). After washing, cells were additionally incubated with the anti-rabbit Alexa 647 secondary antibody (1: 1000; Invitrogen, catalog \#A21244; RRID: AB_141663) to visualize CX3CR1. Ten thousand CD11b + events were acquired on an LSR flow cytometer (BD Biosciences) and analyzed for relative CX3CR1 expression using FlowJo (Tree Star; RRID: nif-0000-30575).

RNA extraction and reverse transcription-PCR. RNA was extracted from isolated microglia using RNeasy spin columns (Qiagen) according to the manufacturer's instructions. Five hundred nanograms of RNA was converted to cDNA using the High Capacity cDNA Reverse Transcription kit (Applied Biosystems) and amplified using specific TaqMan probes on the Applied Biosystems 7300 Real-Time PCR System. Before initiation of the studies, cDNA was serially diluted and amplified using the respective TaqMan probes to ensure that the amount of cDNA used was in the linear range. To quantify the relative expression levels of the different transcripts for each genotype, the difference between cycle threshold (Ct) of the genes of interest and the housekeeping gene Gapdh was calculated as $\Delta \mathrm{Ct}$. From these data, the difference in $\Delta \mathrm{Ct}$ between genotypes of interest and the control APPPS1 genotype was calculated as $\Delta \Delta \mathrm{Ct}$ and expressed as fold change by the formula $2^{\wedge}(-\Delta \Delta \mathrm{Ct})$. These data were tabulated as mean \pm SEM and compared between genotypes using ANOVA followed by Newman-Keuls post hoc test.

\section{Results}

Generation and characterization of APPPS1 mice expressing obligate soluble CX3CL1

CX3CL1 is a type I transmembrane protein with an extracellular chemokine domain that is anchored to the membrane by a mucin-like stalk (Bazan et al., 1997). CX3CL1 can signal to its receptor CX3CR1 in a membrane-anchored form, or as a secreted ligand, upon constitutive and inducible cleavage by ADAM10 and ADAM17 metalloproteinases, respectively (Garton et al., 2001; Hundhausen et al., 2003). To determine the specific contribution of membrane-anchored versus soluble CX3CL1 signaling to $\mathrm{AD}$ pathogenesis, $\mathrm{Cx} 3 \mathrm{cll}$ knock-outs expressing an obligate soluble CX3CL1 transgene $\left(\mathrm{C} x 3 \mathrm{cll}{ }^{-/-}\right.$;SolTg; Kim et al., 2011) were bred to the rapid-onset APPPS1 mouse model of AD (Radde et al., 2006) to generate APPPS1;C $\times 3 c l 1^{-1-}$ and APPPS1; $\mathrm{C} \times 3 \mathrm{Cll}^{-1-}$;SolTg mice. A recent study has demonstrated that SolTg expression restores the defective transepithelial dendrite formation by intestinal macrophages in $\mathrm{Cx} 3 \mathrm{cll} 1^{-1-}$ mice, suggesting that SolTg is clearly functional in the periphery (Kim et al., 2011). However, it has not yet been determined whether SolTg expression affects $\mathrm{AD}$-related pathologies in the CNS.

To confirm CNS expression of the transgene, soluble CX3CL1 levels were measured from aqueous cortical extracts of APPPS1; $\mathrm{C} 3 \mathrm{cll}^{-1-}$;SolTg mice and APPPS1 controls at 4 months by ELISA. APPPS1;C $\times 3 \mathrm{cll}^{-1-}$;SolTg mice exhibited $>60$-fold increase in soluble CX3CL1 in the cortex, compared with APPPS1 controls (data not shown).

\section{Soluble CX3CL1 signaling does not alter fibrillar A $\beta$ deposition in APPPS1 mice}

To assess the effects of soluble versus membrane-anchored CX3CL1 on A $\beta$ deposition, brain sections from APPPS1, APPPS $1 ; C \times 3 \mathrm{cl1}^{-1-}$, and APPPS $1 ; \mathrm{C} \times 3 \mathrm{cll}^{-1-}$;SolTg animals at 4 months of age were stained with thioflavine $S$, a fluorescent dye specific for fibrillar $\mathrm{A} \beta$. Consistent with published reports (Radde et al., 2006), APPPS1 controls exhibited abundant fibril$\operatorname{lar} \mathrm{A} \beta$ deposition in the cortex and to a lesser extent in the hippocampus (Fig. 1A). However, APPPS1;C $\times 3 \mathrm{cl1}^{-1-}$ mice demonstrated reduced fibrillar $A \beta$ deposition in the cortex and the hippocampus compared with APPPS1 controls (Fig. 1B), similar to that previously described in APPPS1;C $\times 3 \mathrm{cr} 1^{-1-}$ mice (Lee et al., 2010). Intriguingly, APPPS1;Cx3cl1 ${ }^{-1-}$;SolTg brains also exhibited reduced $\mathrm{A} \beta$ deposition when compared with APPPS1 controls. The extent of this reduction was indistinguishable from what was observed in APPPS $1 ; C \times 3 \mathrm{Cl1}^{-1-}$ and APPPS1: $\mathrm{C} \times 3 \mathrm{Cr}^{-1-}$ brains (Fig. $1 C$ ). Together, these results demonstrate that expression of soluble CX3CL1 does not alter $\mathrm{A} \beta$ pathology in APPPS1 mice and instead suggest that membrane-anchored CX3CL1 is responsible for regulating $\mathrm{A} \beta$ pathology.

A quantitative analysis of cortical fibrillar $\mathrm{A} \beta$ burden revealed a $36 \%$ reduction in APPPS $1 ; \mathrm{C} \times 3 \mathrm{cll}^{-1-}$ and $49 \%$ reduction in APPPS1; $\mathrm{C} \times 3 \mathrm{cl1}^{-1-}$;SolTg mice when compared with APPPS1 controls $(p<0.01$; Fig. $1 D)$, which was not statistically significantly different from the $43 \%$ reduction in APPPS $1: C \times 3 \mathrm{cr} 1^{-1-}$ mice at the same age. Similarly, hippocampal A $\beta$ deposition was reduced by 53 and $63 \%$ in APPPS $1 ; C \times 3 \mathrm{cl}^{-1-}$ and APPPS1; $\mathrm{C} \times 3 \mathrm{cll} 1^{-1-}$;SolTg animals respectively, when compared with APPPS 1 controls $(p<0.01$ and $p<0.001$, respectively; Fig. $1 E)$, whereas APPPS1:Cx3cr1 ${ }^{-1-}$ mice exhibited a $85 \%$ reduction. Comparisons between APPPS1;Cx3 $\mathrm{Cl}^{-1-}$ and APPPS1;C $\times 3 \mathrm{Cl1}^{-1-}$; SolTg and APPPS1:C $\times 3 \mathrm{cr} 1^{-/-}$genotypes did not yield any statistically significant differences. Together, these data indicate that deficiency in membrane-anchored CX3CL1 signaling ameliorates $\mathrm{A} \beta$ deposition in APPPS 1 animals.

To examine whether the presence of excess ligand in SolTg mice could mediate CX3CR1 internalization, microglia isolated from APPPS1, APPPS1;C $\times 3 \mathrm{cr}^{-/-}$, and APPPS1;C $\times 3 \mathrm{cll}^{-/-}$; SolTg brains at 4 months were analyzed via flow cytometry for 

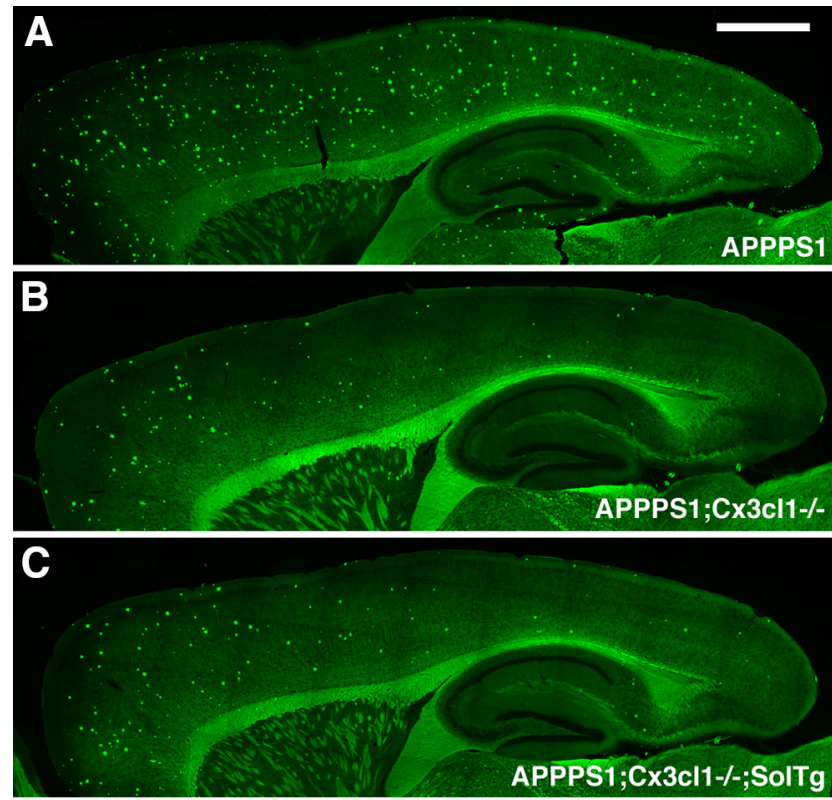

D

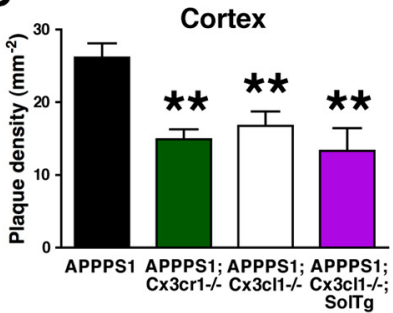

E

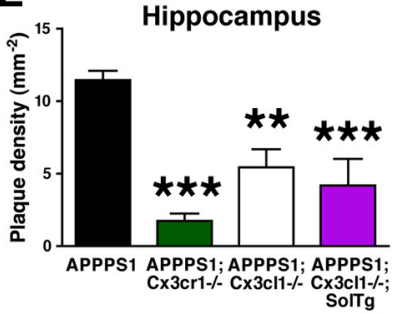

$\mathbf{F}$

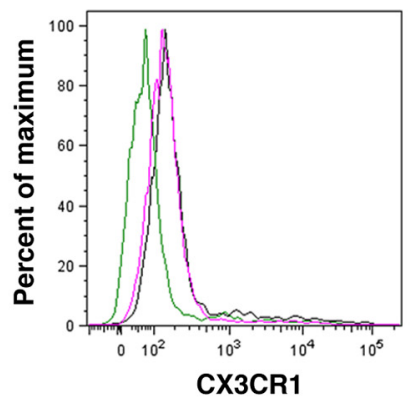

Figure 1. Unaltered fibrillar A $\beta$ deposition in APPPS1 mice expressing obligate soluble

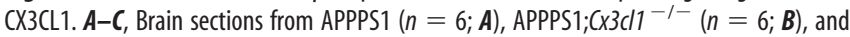
APPPS1; $\left(x 3 \mathrm{Cl}^{-1-} ; \mathrm{SolTg}(n=6 ; C)\right.$ mice at 4 months of age were stained with thioflavine $S$. A series of low-power images (Scale bar, $1 \mathrm{~mm}$ ) were used to reconstruct the cortex and hippocampus from three sections per animal. $\boldsymbol{A}, \boldsymbol{B}, \boldsymbol{D}, \boldsymbol{E}, \mathrm{APPPS1} ;\left(\times 3 \mathrm{C} / 1^{-/-}\right.$mice $(\boldsymbol{B})$ exhibited reduced fibrillar $A \beta$ deposition in the cortex $(\boldsymbol{D})$ and the hippocampus $(\boldsymbol{E})$ compared with age-matched APPPS1 controls $(\boldsymbol{A}) . \mathbf{C}-\boldsymbol{E}$, However, expression of SolTg in APPPS1; $\left(\mathrm{C}_{3} \mathrm{Cl} 1^{-1-}\right.$ mice $(\boldsymbol{C})$ did not additionally alter fibrillar $A \beta$ deposition in either brain regions $(\boldsymbol{D}, \boldsymbol{E})$. Quantification of fibrillar $A \beta$ deposition in APPPS1; $\left(\times 3 \mathrm{Cr}^{-1-}\right.$ mice $(n=7)$ from a previous study (Lee et al., 2010) is included as reference $\left(\boldsymbol{D}, \boldsymbol{E}_{*}{ }^{* *} p<0.01\right.$, ${ }^{* * *} p<0.001$, 1-way ANOVA with Newman-Keuls post hoc test). $\boldsymbol{F}$, To determine the effect of SolTg on membrane CX3CR1 expression, microglia isolated from APPPS1 (black), APPPS1; $\times 33 \mathrm{Cr}^{-1-}$ (green), and APPPS1; $C \times 3 \mathrm{Cl} 1^{-1-} ;$; SolTg mice (purple) were analyzed by flow cytometry. CD11b + gated cells from APPPS1 and APPPS1; $\mathrm{CX} 3 \mathrm{Cl}^{-1-}$; SolTg brains expressed comparable levels of membrane $\mathrm{XX} 3 \mathrm{CR} 1$, whereas no CX3CR1 expression was detected in APPPS1; $\mathrm{CX}_{\mathrm{Cr}}{ }^{-1-}$ cells. These are the result of two experiments.

membrane CX3CR1 expression. Notably, despite elevated soluble CX3CL1 levels in the SolTg mice, CX3CR1 expression was grossly unaltered in microglia from APPPS $1 ; \mathrm{C} 3 \mathrm{cll}^{-1-}$;SolTg mice, when compared with microglia from APPPS1 controls (Fig. $1 F$ ).
A

APPPS1;

APPPS1; APPPS1; Cx3cl1-/-; APPPS1 Cx3cr1-/- Cx3cl1-\% SolTg

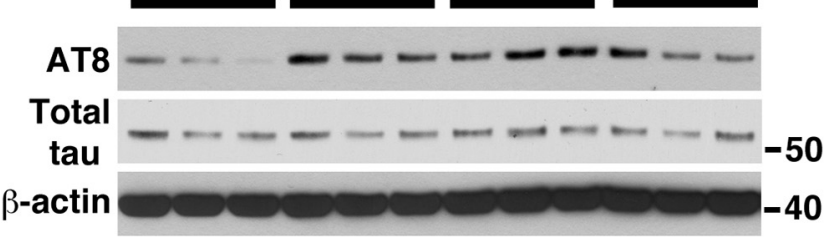

B

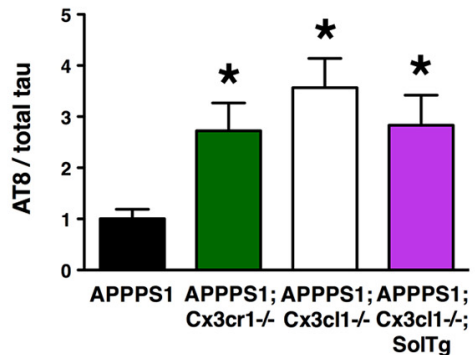

C

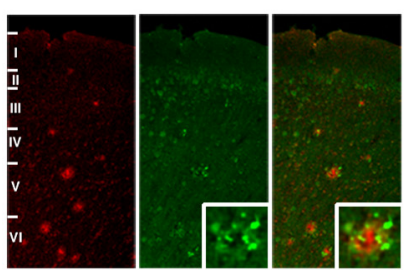

D

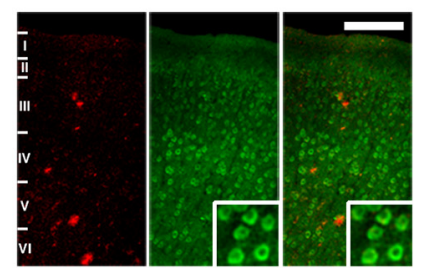

Figure 2. Hyperphosphorylation of MAPT in APPPS1 mice lacking membrane-anchored CX3CL1 signaling. A, Western blots of cortical lysates from APPPS1 $(n=6), \operatorname{APPPS1;} \times \mathrm{X} 3 \mathrm{Cr}^{-1-}$ $(n=5), \operatorname{APPPS1} ;\left(\times 3 \mathrm{Cl} 1^{-1-}(n=4)\right.$, and APPPS1; $\left(\times 3 \mathrm{Cl}^{-1-} ;\right.$ SolTg mice $(n=4)$ at 4 months were probed with antibodies against phospho-MAPT (AT8), total MAPT, and $\beta$-actin. B, Quantification of band intensities revealed significant increases in AT8-reactive MAPT relative to total MAPT expression in APPPS1; $C \times 3 \mathrm{Cr}^{-1-}$, APPPS1; $\times 33 \mathrm{Cl}^{-1-}$, and APPPS1; $\times 3 \mathrm{Cl}^{-1-}$; SolTg genotypes compared with APPPS1 controls. C, D, Immunostaining brain sections for $A \beta$ with monoclonal 4G8 antibody (red) and AT8 antibody (green) revealed pronounced phospho-MAPT accumulation within layer IV/V cortical pyramidal neurons of APPPS1; $C \times 3 \mathrm{Cl} 1^{-1-}$ mice $(\boldsymbol{D}$, insets), which was not observed in APPPS1 controls ( $\boldsymbol{C}$, insets). Scale bar, $100 \mu \mathrm{m}$; ${ }^{*} p<0.05$, one-way ANOVA with Newman-Keuls post hoc test.

Deficiency in membrane-anchored CX3CL1 signaling enhances MAPT phosphorylation

Previous results have suggested that CX3CR1 deficiency exacerbates neuronal MAPT phosphorylation and aggregation in hTau animals via enhanced IL1/p38 MAPK signaling (Bhaskar et al., 2010). To assess the effects of soluble and membrane-anchored CX3CL1 on altered intraneuronal MAPT phosphorylation in APPPS1 animals, cortical lysates from APPPS1, APPPS1; $\mathrm{C} \times 3 \mathrm{cr}^{-/-}$, APPPS $1 ; \mathrm{C} \times 3 \mathrm{cl1} 1^{-/-}$, and APPPS $1 ; \mathrm{C} \times 3 \mathrm{cl1} 1^{-/-} ; \mathrm{SolTg}$ mice were analyzed by Western blot for the levels of phosphoMAPT using the AT8 monoclonal antibody (Fig. 2A). Surprisingly, despite reduced $\mathrm{A} \beta$ deposition, APPPS1;C $\times 3 \mathrm{cr} 1^{-1-}$,

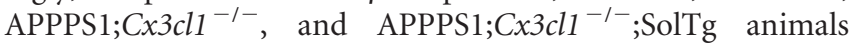
exhibited a $\sim 2.5$-fold, $\sim 3.5$-fold, and $\sim 2.5$-fold increase in AT8/ total MAPT ratio, respectively, when compared with APPPS1 controls $(p<0.05$; Fig. $1 B)$. Contrary to the results for $A \beta$ deposition, these findings suggest that deficiency in membraneanchored CX3CL1 signaling promotes intraneuronal MAPT phosphorylation.

To determine the localization of phospho-MAPT, brain sections from APPPS1 and APPPS $1 ; C \times 3 \mathrm{cl}^{-1-}$ mice were immuno- 
stained with the phospho-MAPT AT8 antibody (Fig. 2C,D, green) and the monoclonal $\mathrm{A} \beta$ antibody $4 \mathrm{G} 8$ (Fig. $2 C, D$, red). Consistent with previous data (Radde et al., 2006), AT8 immunoreactivity in the cortex of APPPS1 mice was largely restricted to the immediate vicinity of $\mathrm{A} \beta$ deposits (Fig. $2 C$, insets). By contrast, APPPS1; $\mathrm{C} \times 3 \mathrm{cll}^{-1-}$ mice exhibited pronounced intraneuronal phosphoMAPT accumulation, especially within cortical layer IV/V pyramidal cells (Fig. $2 D$, insets). Interestingly, the expression pattern of intraneuronal phospho-MAPT in APPPS1; $\mathrm{Cx}_{3} \mathrm{Cl}^{-/-}$animals closely resembled the expression pattern of endogenous CX3CL1 observed in Cx3cl1 ${ }^{\text {mCherry }}$ BAC reporter mice (Kim et al., 2011). In summary, the data presented here suggest that membrane-anchored CX3CL1 has apparent opposing effects on $\mathrm{AD}$ pathologies, with reductions in extracellular $\mathrm{A} \beta$ deposition but increases in intraneuronal MAPT phosphorylation.

\section{Absence of membrane-anchored CX3CL1 signaling in APPPS1 mice alters microglial gene expression}

To gain insight into the potential mechanisms underlying the divergent effects of membrane-anchored CX3CL1 signaling on $\mathrm{A} \beta$ and MAPT pathologies in APPPS1 mice, microglia were purified from APPPS1, APPPS1;Cx3 $\mathrm{cr}^{-1-}$, APPPS1;C $\mathrm{C}_{3} \mathrm{Cl}^{-1-}$, and APPPS1;CX3 $\mathrm{Cl1}^{-1-} ;$ SolTg brains at 4 months and examined for expression of various inflammatory and $\mathrm{AD}$-relevant transcripts using quantitative RT-PCR (Fig. 3). Inclusion of all the different genotypes proved valuable in screening for relevant genes that demonstrate similar alterations in the APPPS1;

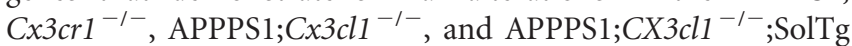
samples when compared with APPPS1 controls.

RNA from purified microglia was reverse-transcribed and assayed in triplicate for relative expression of cytokines/inflammatory molecules that have been shown to alter microglial activation and $\mathrm{A} \beta$ pathology in $\mathrm{AD}$ mouse models, including complement component 3, cyclooxygenase-1 (COX1), COX2, IFN $\gamma$, IL1 $\alpha$, IL1 $\beta$, IL4, IL6, IL10, IL12A, IL12B, monocyte chemotactic protein 1 , nitric oxide synthase $2, \operatorname{TGF} \beta$, and TNF $\alpha$ (Lim et al., 2000; Wyss-Coray et al., 2001; Yamamoto et al., 2005; Maier et al., 2008; Chakrabarty et al., 2010a,b, 2011, 2012; Kummer et al., 2011; Vom Berg et al., 2012; Ghosh et al., 2013). Furthermore, relative expression of molecules implicated in $A \beta$ clearance, including $\mathrm{A} \beta$ phagocytic receptors $(\mathrm{CD} 11 \mathrm{~b}, \mathrm{CD} 36$, LDL-related receptor protein 1, MSR1, and receptor for advanced glycation end-products), as well as $A \beta$-degrading enzymes (cathepsin B, insulin-degrading enzyme, matrix metalloproteinase 9 , and neprilysin), were determined.

Importantly, while the expression levels of most of the genes examined did not exhibit a reproducible pattern of expression across the four genotypes examined, three genes exhibited consistent alterations that correlated with the effects on $\mathrm{A} \beta$ deposition. First, the relative mRNA levels of inflammatory cytokine IL1 $\alpha$ were significantly increased in APPPS1;C $\times 3 c r 1^{-1-}(p<0.05)$, APPPS1; $C \times 3 c l 1^{-1-}(p<0.001)$, and APPPS1;Cx3cl1 ${ }^{-1-} ; \operatorname{SolTg}(p<0.001)$ microglia when compared with APPPS1 controls (Fig. 3A). Second, expression levels of another inflammatory cytokine, IL6, were also upregulated in APPPS1;C $\times 3 \mathrm{Cr}^{-1-}$, APPPS1;C $\times 3 \mathrm{Cl1}^{-1-}$, and APPPS1;C $C 3 \mathrm{Cl1}^{-1-} ;$ SolTg microglia compared with APPPS1 controls ( $p<0.01$; Fig. $3 B$ ). Third, isolated microglia from APPPS1;
$\mathrm{C} \times 3 \mathrm{Cr}^{-1-}$, APPPS1;C $\times 3 \mathrm{Cl}^{-1-}$, and APPPS1;C $\times 3 \mathrm{Cl1}^{-/-} ;$SolTg mice exhibited increased expression of MSR1 mRNA, which encodes an A $\beta$ phagocytic receptor $(p<0.05$; Fig. $3 C)$. Together, these studies reveal altered microglial gene expression that could contribute to the effects of membrane-anchored CX3CL1 on A $\beta$ and MAPT pathologies.

\section{CX3CL1 deficiency enhances microglial A $\beta$ uptake in APPPS1 mice}

The gene expression studies suggested that expression of MSR 1 is elevated within microglia lacking signaling from membraneanchored CX3CL1. Notably, considerable evidence suggests that MSR1 mediates A $\beta$ binding and phagocytosis (Paresce et al., 1996; Michaud et al., 2013). To examine whether upregulation of microglial MSR1 expression in APPPS1 mice lacking CX3CL1 promotes enhanced $\mathrm{A} \beta$ uptake, brain sections from APPPS1 (Fig. $4 A-C)$, APPPS1;Cx3cr1 ${ }^{-1-}$ (Fig. $4 D-F$ ), APPPS1;Cx3 $\mathrm{cll}^{-1-}$ (Fig. 4G-I), and APPPS1;Cx3cl1 ${ }^{-1-}$;SolTg mice (Fig. $4 J-L$ ) were coimmunostained with an antibody against the microglial marker Ibal (Fig. $4 A, C, D, F, G, I, J, L$, green) and the monoclonal $\mathrm{A} \beta$ antibody 4G8 (Fig. $4 B, C, E, F, H, I, K, L$, red). Microglia from APPPS1;CX3 $\mathrm{cr}^{-1-}$ (Fig. 4E,F, insets, arrowheads), APPPS1; $\mathrm{C} 3 \mathrm{Cll}^{-1-}$ (Fig. 4H,I, insets, arrowheads), and APPPS1; $\mathrm{C} 3 \mathrm{Cll}^{-1-}$;SolTg animals (Fig. $4 \mathrm{~K}, L$, insets, arrowheads) exhibited increased $A \beta$ internalization compared with APPPS1 controls. Quantification of $A \beta$ internalized by plaque-adjacent microglia revealed $\sim 2$-fold increase in the $\mathrm{A} \beta$ volume per cell in APPPS1; $\mathrm{C}_{3} 3 \mathrm{Cr}^{-1-}$, APPPS1;C $\times 3 \mathrm{Cl}^{-1-}$, and APPPS1;C $\times 3 \mathrm{Cl1}^{-1-}$; SolTg mice compared with APPPS1 controls $(p<0.001, p<0.01$, and $p<0.001$, respectively; Fig. $4 G$ ). Together, these data suggest that reduced fibrillar $\mathrm{A} \beta$ deposition observed in APPPS1 mice in the absence of membrane-anchored CX3CL1 signaling may be mediated by enhanced MSR1-dependent phagocytosis of $A \beta$.

\section{Absence of membrane-anchored CX3CL1 signaling enhances p38 MAPK activation in APPPS1 mice}

Cell-type-specific p38 MAPK signaling has been implicated in several aspects of $\mathrm{AD}$ pathogenesis, including microglial response to $A \beta$, neuronal MAPT phosphorylation, and inflammatory $c y-$ tokine signaling. In particular, p38 MAPK activation promoted $\mathrm{A} \beta$-induced microglial phagocytosis in vitro (Reed-Geaghan et al., 2009). Furthermore, enhanced p38 MAPK activation was associated with greater microglial expression of MSR1, as well as increased $\mathrm{A} \beta$ phagocytosis, resulting in reduced $\mathrm{A} \beta$ burden in an AD mouse model (Michaud et al., 2013). By contrast, inflammatory cytokine-mediated p38 MAPK activation in neurons has been consistently linked to exacerbation of MAPT pathology ( $\mathrm{Li}$ et al., 2003; Bhaskar et al., 2010). 


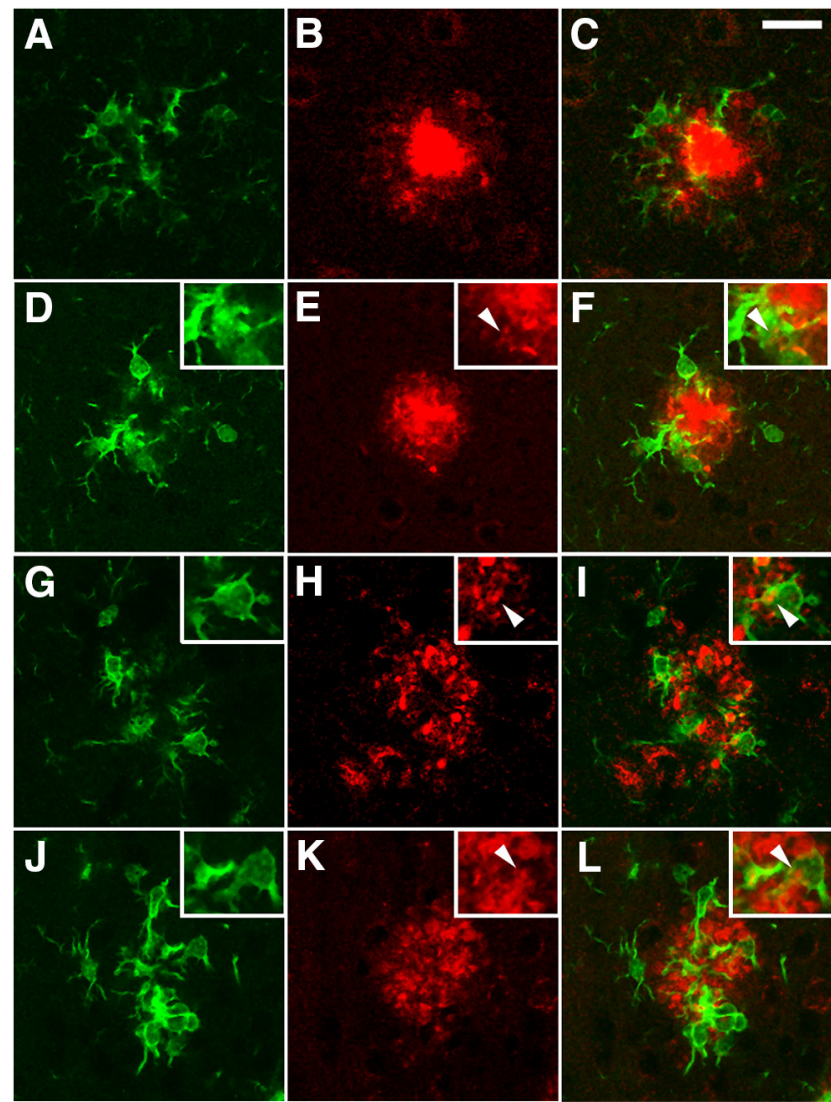

M

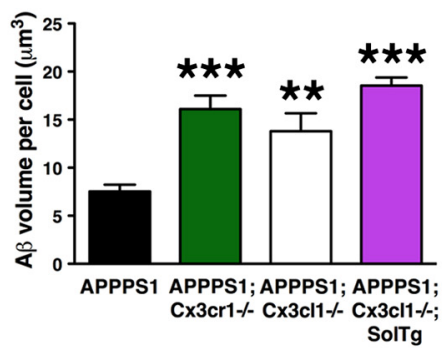

Figure 4. Enhanced microglial $A \beta$ phagocytosis in APPPS1 mice lacking membraneanchored XXCL1 signaling. $A-L$, Brain sections from 4-month-old APPPS1 ( $A-C$ ) and APPPS1;

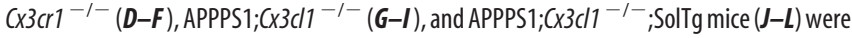
immunostained with the antibody against the microglial marker $\operatorname{lba} 1(A, C, D, F, G, I, J, L$, green) and the monoclonal $A \beta$ antibody $4 G 8(B, C, E, F, H, I, K, L$, red) $. C, E, F, K, L, M$, Quantification of $A \beta$ phagocytosis $(M)$ revealed increased intracellular $A \beta$ volume per cell in APPPS1; C $\times 3 C r 1^{-1-}\left(\boldsymbol{E}, \boldsymbol{F}\right.$, insets, arrowheads), APPPS1; $C \times 3 C 11^{-1-}(\boldsymbol{H}, \boldsymbol{I}$, insets, arrowheads), and APPPS1; $\times$ X3Cl1 ${ }^{-\prime-}$;SolTg mice $(\boldsymbol{K}, \boldsymbol{L}$, insets, arrowheads) compared with APPPS1 controls (C). Scale bar, $25 \mu \mathrm{m} ;{ }^{* *} p<0.01,{ }^{* * *} p<0.001$, one-way ANOVA with Newman-Keuls post hoc test.

To determine potential consequences of altered microglial activation on cell-type-specific p38 MAPK signaling, brain sections from APPPS1 (Fig. $5 A-C$ ) and APPPS1;C $\times 3 \mathrm{cll}^{-1-}$ mice (data not shown) were immunostained with an antibody against CD45, a marker for hematopoietic cells upregulated in activated microglia (Fig. 5A,C, red), an antibody against active phospho-p38 MAPK (Fig. $5 B, C$, green), and an antibody against $\mathrm{A} \beta$ (Fig. $5 A-C$, blue). Most phospho-p38 MAPK immunoreactivity was localized to CD45-positive, plaque-adjacent microglia in APPPS1 (Fig. 5C) and APPPS1;C $\times 3 \mathrm{cl1}^{-1-}$ animals (data not shown). By contrast, phospho-p38 MAPK expression was unde-
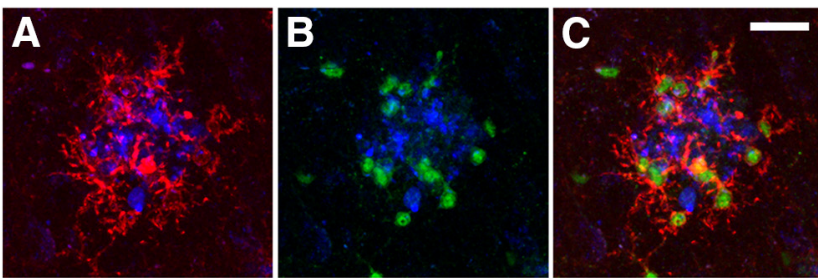

D

APPPS1;

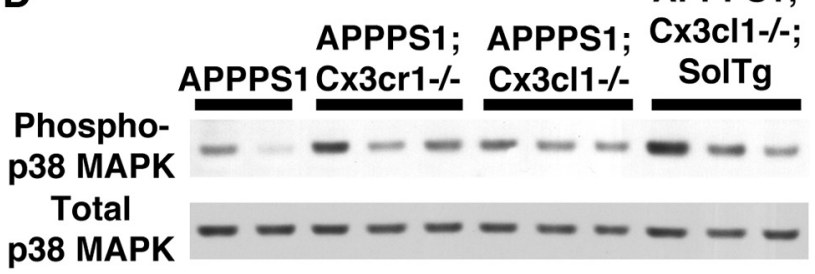

E

APPPS1; APPPS1; APPPS1; Cx3cl1-/-;

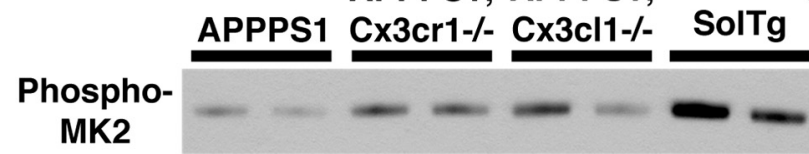

$\beta$-actin

F

G
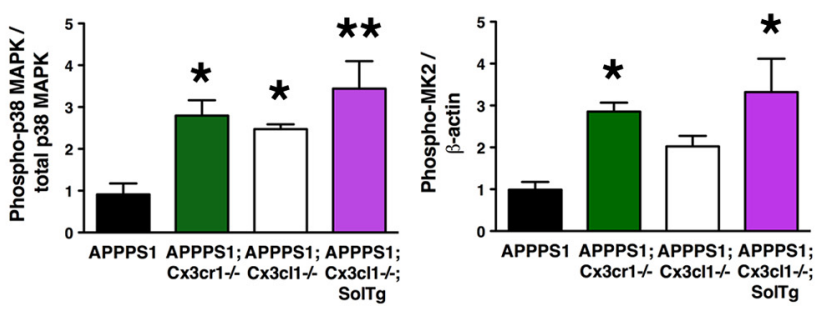

Figure 5. Increased $\mathrm{p} 38$ MAPK activation in APPPS1 mice lacking membrane-anchored CX3CL1 signaling. A-C, Immunostaining with the antibody against CD45, a marker for cells of hematopoietic lineage upregulated in activated microglia $(A, C$, red), the antibody against phospho-p38 MAPK ( $\boldsymbol{B}, \boldsymbol{C}$, green), and the monoclonal $A \beta$ antibody $4 \mathrm{G} 8$ ( $\boldsymbol{A}-\boldsymbol{C}$, blue) revealed predominant localization of phospho-p38 MAPK within plaque-adjacent microglia in APPPS1 mice at 4 months (C). D. Western blots of cortical lysates from APPPS1 $(n=4)$, APPPS1;

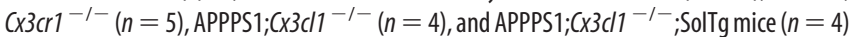
at 4 months were probed with anti-phospho-p38 MAPK and total p38 MAPK antibodies. $\boldsymbol{F}$, Quantification of band intensities revealed increased phopho-p38 MAPK levels relative to total p38 MAPK levels in APPPS1; $\left(\times 3 \mathrm{Cr}^{-1-}\right.$, APPPS1; $C \times 3 \mathrm{Cl}^{-1-}$, and APPPS1; $\mathrm{C} 3 \mathrm{Cl} 1^{-1-} ; \mathrm{SolTg}$ mice compared with APPPS1 controls. $\boldsymbol{E}, \mathbf{G}$, In addition, Western blot analysis of cortical lysates for phospho-MAPKAPK2 expression relative to $\beta$-actin $(\boldsymbol{E})$ revealed significant increases in APPPS1; $\times 33 \mathrm{Cr}^{-1-}(n=5)$ and APPPS1; $\left(\times 3 \mathrm{Cl1} 1^{-1-} ;\right.$ SolTg mice $(n=4)$ compared with APPPS1 controls $\left(n=6\right.$; $G$ ). Scale bar, $25 \mu \mathrm{m} ;{ }^{*} p<0.05,{ }^{* *} p<0.01$, one-way ANOVA with Newman-Keuls post hoc test.

tectable in neurons and astrocytes by immunohistochemistry (data not shown), although this result clearly does not rule out the contribution of neuronal phospho-p38 MAPK to MAPT phosphorylation.

Since active p38 MAPK is observed in numerous cells and observed at especially high levels in microglia, phospho-p38 MAPK immunohistochemistry could not be readily quantified. Instead, Western blots of cortical lysates from APPPS1, APPPS1; $\mathrm{C} \times 3 \mathrm{cr} 1^{-1-}$, APPPS $1 ; \mathrm{C} \times 3 \mathrm{cll} 1^{-1-}$, and APPPS $1 ; \mathrm{C} \times 3 \mathrm{cll}^{-1-} ;$ SolTg mice were probed with antibodies specific for total or active $\mathrm{p} 38$ MAPK (phosphorylated at T180/Y182; Fig. 5D). Quantitative analysis of the Western blots revealed that APPPS1;CX3 $\mathrm{cr} 1^{-1-}$, 
APPPS1;C $\times 3 \mathrm{cll}^{-1-}$, and APPPS $1 ; C \times 3 \mathrm{cll}^{-1-} ;$ SolTg mice exhibit a $\sim 3$-fold, $\sim 2.5$-fold, and $\sim 3$-fold increase in phospho-p38 MAPK/total p38 MAPK ratio when compared with APPPS1 controls $(p<0.05, p<0.05$, and $p<0.01$, respectively; Fig. $5 F)$.

To examine whether activation of p38 MAPK leads to alterations in phosphorylation of downstream substrates (in addition to MAPT), the levels of phosphorylation of mitogen-activated protein kinase-activated protein kinase 2 (MAPKAPK2, also known as MK2) were also determined in the cortical lysates (Fig. 5E). Quantitative analysis of the Western blots revealed a $\sim 3$-fold, $\sim 2$ fold, and $\sim 3$-fold increase in phospho-MAPKAPK2/ $\beta$-actin ratio in APPPS1;C $33 \mathrm{crl}^{-1-}(p<0.05)$, APPPS1;C $33 \mathrm{cl} 1^{-/-}$(not significant), and APPPS1;C $\times 3 \mathrm{cl1}^{-/-}$;SolTg mice $(p<0.05)$ when compared with APPPS1 controls (Fig. $5 G$ ). In summary, these results demonstrate that altered microglial activation in APPPS1 mice lacking membrane-anchored CX3CL1 signaling leads to enhanced p38 MAPK pathway activation.

\section{Discussion}

The findings presented here offer novel insights into the relative contribution of membrane-anchored versus soluble CX3CL1 signaling in the development of $\mathrm{A} \beta$ and MAPT pathologies in APPPS1 mice. Consistent with results from previous studies characterizing receptor knock-outs (Lee et al., 2010), APPPS1; $\mathrm{C} \times 3 \mathrm{Cl1}^{-1-}$ mice exhibited reduced $\mathrm{A} \beta$ deposition at 4 months of age. However, despite this reduction in amyloid burden, CX3CL1 deficiency enhanced intraneuronal phospho-MAPT accumulation. Importantly, expression of obligate soluble CX3CL1 did not additionally alter the $\mathrm{A} \beta$ and MAPT phenotypes observed in APPPS1; $\mathrm{C} \times 3 \mathrm{Cl1}^{-1-}$ animals, suggesting that membraneanchored CX3CL1 selectively alters AD-related phenotypes in APPPS1 mice. Notably, microglia from APPPS1 mice lacking membrane-anchored CX3CL1 had increased levels of IL1 $\alpha$, IL6, and MSR1, which was consistent with increased activation of p38 MAPK and $\mathrm{A} \beta$ phagocytosis observed in these animals.

In addition to enhancing $\mathrm{A} \beta$ phagocytosis, CX3CL1 deficiency also resulted in an increase in intraneuronal MAPT. The divergent role of fractalkine signaling on different $\mathrm{AD}$ pathologies is consistent with evidence from other neurodegenerative diseases. For example, CX3CR1 deficiency exacerbated neuronal loss in a toxin model of Parkinson's disease, in a transgenic model of amyotrophic lateral sclerosis, and upon induction of neuroinflammation by systemic lipopolysaccharide administration (Cardona et al., 2006). On the other hand, Cx3crl knock-out mice exhibited reduced ischemic lesion volume after middle cerebral artery occlusion and improved recovery after spinal cord injury (Dénes et al., 2008; Donnelly et al., 2011). These previous results suggested that CX3CL1-CX3CR1 signaling may alternatively exacerbate or ameliorate neurodegenerative phenotypes based upon the nature and duration of the CNS insult. Furthermore, the results in the current study suggest that the opposing effects of blocking CX3CL1-CX3CR1 signaling can occur even within the same animal, promoting phagocytic removal of $\mathrm{A} \beta$ on the one hand, but also enhancing intraneuronal MAPT phosphorylation on the other.

CX3CL1 is a unique chemokine in that it can signal in both a membrane-anchored form and a soluble form when released by ADAM10/17 cleavage (Garton et al., 2001; Hundhausen et al., 2003). A recent study demonstrated that ADAM10 mutations associated with late-onset $\mathrm{AD}$ impair the enzyme's $\alpha$-secretase activity (Suh et al., 2013). In addition to affecting ADAM10mediated APP cleavage, these mutations would also lead to altered CX3CL1 processing, likely increasing the relative levels of membrane-anchored CX3CL1 compared with the soluble form. This means that dissecting the role of soluble and membraneanchored CX3CL1 may be important for understanding the pathogenesis of these ADAM10 mutations. Various experimental approaches have been used to determine the relative contributions of membrane-anchored and soluble forms of CX3CL1 in vivo (Kim et al., 2011; Morganti et al., 2012; Nash et al., 2013). The current study has expanded these findings to examine the role of membrane-anchored and soluble CX3CL1 in the development of $\mathrm{A} \beta$ and MAPT pathologies within the CNS of the APPPS1 mouse model of AD, through an examination of APPPS1, APPPS $1 ; C \times 3 \mathrm{Cl1}^{-1-}$, and APPPS $1 ; \mathrm{C} \times 3 \mathrm{cll} 1^{-1-} ;$ SolTg mice. CX3CL1-deficient APPPS1 animals exhibited reduced A $\beta$ deposition (Fig. 1) but enhanced MAPT phosphorylation (Fig. 2) compared with APPPS1 controls. However, APPPS1;Cx3cl1 ${ }^{-1-}$; SolTg mice did not exhibit any significant changes in $\mathrm{A} \beta$ and MAPT pathologies compared with APPPS1;C $\times 3 \mathrm{cl1}^{-1-}$ genotypes, suggesting that alterations in AD pathologies in CX3CR1deficient or CX3CL1-deficient APPPS1 animals are mediated by the absence of membrane-anchored but not soluble CX3CL1 signaling. If ADAM10 mutations increase membrane-anchored CX3CL1, this would result in increased fracktaline signalingdependent $\mathrm{A} \beta$ deposition, providing an additional mechanism by which ADAM10 mutations could lead to enhanced amyloid pathology.

These conclusions should be further validated by additional experiments that selectively manipulate membrane-anchored CX3CL1 signaling. For instance, this could be accomplished by transgenic expression of ADAM10/17 cleavage-resistant CX3CL1 in APPPS $1 ; \mathrm{Cx}_{3} \mathrm{Cl}^{-/-}$animals. Unfortunately, design of such a CX3CL1 molecule will be difficult. Given the general lack of cleavage-site sequence specificity among the ADAM metalloproteinases (Janes et al., 2005), broad changes in the CX3CL1 sequence will be necessary to affect its proteolytic shedding. A second potential approach is to inhibit ADAM10/17 in APPPS1 animals, but this will likely lead to untoward effects due to multiple ADAM10/17 substrates (Caescu et al., 2009). Therefore, these future studies await better understanding of CX3CL1 biology and development of more specific CX3CL1 cleavage inhibitors.

Microglia from various genotypes of APPPS1 mice lacking membrane-anchored CX3CL1-CX3CR1 signaling demonstrated increased levels of inflammatory cytokines IL $1 \alpha$ and IL6 as well as increased expression of the A $\beta$ phagocytic receptor MSR1 (Fig. 3 ), suggesting altered microglial activation and phagocytic responses. Consistent with the involvement of MSR1 in microglial phagocytosis (Paresce et al., 1996; Michaud et al., 2013), plaqueassociated microglia of APPPS1 mice lacking membraneanchored CX3CL1 exhibited enhanced A $\beta$ uptake compared with APPPS1 controls (Fig. 4). These data provide evidence contrary to the current theory that microglia in the AD brain exhibit poor $\mathrm{A} \beta$ phagocytosis due to age-dependent and inflammationdependent functional decline (Koenigsknecht-Talboo et al., 2008; Streit et al., 2009; Njie et al., 2012). Our data challenge this "frustrated phagocytosis" concept in that CX3CL1/CX3CR1-deficient APPPS 1 animals have efficient $\mathrm{A} \beta$ phagocytosis, despite the presence of sufficient inflammatory activity to drive MAPT pathology. This suggests that microglia in $\mathrm{AD}$ have the capacity to phagocytose $\mathrm{A} \beta$, even in the context of an inflammatory environment.

Previous studies have demonstrated that p38 MAPK signaling in microglia promotes $\mathrm{A} \beta$ phagocytosis (Reed-Geaghan et al., 2009) as well as upregulation of MSR1 (Michaud et al., 2013), whereas neuronal p38 MAPK enhances MAPT phosphorylation (Li et al., 2003). Therefore, cell-type-specific p38 MAPK signaling 
could potentially mediate the divergent $A \beta$ and MAPT phenotypes observed in our studies. Indeed, APPPS1 animals lacking membrane-anchored CX3CL1 signaling exhibited a greater activation of the p38 MAPK pathway compared with APPPS1 controls, predominantly within microglia, although neuronal expression cannot be excluded (Fig. 5). Therefore, we hypothesize that the divergent effects of membrane-anchored CX3CL1 signaling on $\mathrm{A} \beta$ and MAPT pathologies arise from the propensity of p38 MAPK signaling to enhance $A \beta$ clearance but exacerbate MAPT phosphorylation. We postulate that the deficiency in membrane-anchored CX3CL1 signaling increases microglial production of IL1 $\alpha$ and IL6 in response to A $\beta$. In turn, these cytokines activate p38 MAPK in neurons and microglia, leading to intraneuronal phospho-MAPT accumulation and increased MSR1-mediated $\mathrm{A} \beta$ phagocytosis, respectively.

In conclusion, this study demonstrates the opposing effects of isoform-specific CX3CL1 signaling and microglial activation on the development of $\mathrm{A} \beta$ and MAPT pathologies. Given the importance of CX3CL1-CX3CR1 interaction in regulating microglial activation and neurodegenerative phenotypes, this unique ligandreceptor pair has received considerable attention as a potential therapeutic target in CNS diseases. Our data suggest that any pharmacological agent that alters CX3CL1 signaling in $\mathrm{AD}$ must target specific CX3CL1 isoforms and that therapeutic strategies geared toward altering microglial activation for removal of $A \beta$ must take into account its potential effects on intraneuronal MAPT pathologies.

\section{References}

Bazan JF, Bacon KB, Hardiman G, Wang W, Soo K, Rossi D, Greaves DR, Zlotnik A, Schall TJ (1997) A new class of membrane-bound chemokine with a CX3C motif. Nature 385:640-644. CrossRef Medline

Bhaskar K, Konerth M, Kokiko-Cochran ON, Cardona A, Ransohoff RM, Lamb BT (2010) Regulation of tau pathology by the microglial fractalkine receptor. Neuron 68:19-31. CrossRef Medline

Caescu CI, Jeschke GR, Turk BE (2009) Active-site determinants of substrate recognition by the metalloproteinases TACE and ADAM10. Biochem J 424:79-88. CrossRef Medline

Cardona AE, Pioro EP, Sasse ME, Kostenko V, Cardona SM, Dijkstra IM, Huang D, Kidd G, Dombrowski S, Dutta R, Lee JC, Cook DN, Jung S, Lira SA, Littman DR, Ransohoff RM (2006) Control of microglial neurotoxicity by the fractalkine receptor. Nat Neurosci 9:917-924. CrossRef Medline

Chakrabarty P, Jansen-West K, Beccard A, Ceballos-Diaz C, Levites Y, Verbeeck C, Zubair AC, Dickson D, Golde TE, Das P (2010a) Massive gliosis induced by interleukin-6 suppresses Abeta deposition in vivo: evidence against inflammation as a driving force for amyloid deposition. FASEB J 24:548-559. CrossRef Medline

Chakrabarty P, Ceballos-Diaz C, Beccard A, Janus C, Dickson D, Golde TE, Das P (2010b) IFN-gamma promotes complement expression and attenuates amyloid plaque deposition in amyloid beta precursor protein transgenic mice. J Immunol 184:5333-5343. CrossRef Medline

Chakrabarty P, Herring A, Ceballos-Diaz C, Das P, Golde TE (2011) Hippocampal expression of murine TNFalpha results in attenuation of amyloid deposition in vivo. Mol Neurodegener 6:16. CrossRef Medline

Chakrabarty P, Tianbai L, Herring A, Ceballos-Diaz C, Das P, Golde TE (2012) Hippocampal expression of murine IL-4 results in exacerbation of amyloid deposition. Mol Neurodegener 7:36. CrossRef Medline

Dénes A, Ferenczi S, Halász J, Környei Z, Kovács KJ (2008) Role of CX3CR1 (fractalkine receptor) in brain damage and inflammation induced by focal cerebral ischemia in mouse. J Cereb Blood Flow Metab 28:1707-1721. CrossRef Medline

Donnelly DJ, Longbrake EE, Shawler TM, Kigerl KA, Lai W, Tovar CA, Ransohoff RM, Popovich PG (2011) Deficient CX3CR1 signaling promotes recovery after mouse spinal cord injury by limiting the recruitment and activation of Ly6Clo/iNOS+ macrophages. J Neurosci 31:9910-9922. CrossRef Medline

Garton KJ, Gough PJ, Blobel CP, Murphy G, Greaves DR, Dempsey PJ, Raines EW
(2001) Tumor necrosis factor-alpha-converting enzyme (ADAM17) mediates the cleavage and shedding of fractalkine (CX3CL1). J Biol Chem 276:3799338001. Medline

Ghosh S, Wu MD, Shaftel SS, Kyrkanides S, LaFerla FM, Olschowka JA, O’Banion MK (2013) Sustained interleukin-1 $\beta$ overexpression exacerbates tau pathology despite reduced amyloid burden in an Alzheimer's mouse model. J Neurosci 33:5053-5064. CrossRef Medline

Guerreiro R, Wojtas A, Bras J, Carrasquillo M, Rogaeva E, Majounie E, Cruchaga C, Sassi C, Kauwe JS, Younkin S, Hazrati L, Collinge J, Pocock J, Lashley T, Williams J, Lambert JC, Amouyel P, Goate A, Rademakers R, Morgan K, et al. (2013) TREM2 variants in Alzheimer's disease. N Engl J Med 368:117-127. CrossRef Medline

Hollingworth P, Harold D, Sims R, Gerrish A, Lambert JC, Carrasquillo MM, Abraham R, Hamshere ML, Pahwa JS, Moskvina V, Dowzell K, Jones N, Stretton A, Thomas C, Richards A, Ivanov D, Widdowson C, Chapman J, Lovestone S, Powell J, et al. (2011) Common variants at ABCA7, MS4A6A/MS4A4E, EPHA1, CD33 and CD2AP are associated with Alzheimer's disease. Nat Genet 43:429-435. CrossRef Medline

Hundhausen C, Misztela D, Berkhout TA, Broadway N, Saftig P, Reiss K, Hartmann D, Fahrenholz F, Postina R, Matthews V, Kallen KJ, Rose-John S, Ludwig A (2003) The disintegrin-like metalloproteinase ADAM10 is involved in constitutive cleavage of CX3CL1 (fractalkine) and regulates CX3CL1-mediated cell-cell adhesion. Blood 102:1186-1195. CrossRef Medline

Janes PW, Saha N, Barton WA, Kolev MV, Wimmer-Kleikamp SH, Nievergall E, Blobel CP, Himanen JP, Lackmann M, Nikolov DB (2005) Adam meets Eph: an ADAM substrate recognition module acts as a molecular switch for ephrin cleavage in trans. Cell 123:291-304. CrossRef Medline

Jonsson T, Stefansson H, Steinberg S, Jonsdottir I, Jonsson PV, Snaedal J, Bjornsson S, Huttenlocher J, Levey AI, Lah JJ, Rujescu D, Hampel H, Giegling I, Andreassen OA, Engedal K, Ulstein I, Djurovic S, IbrahimVerbaas C, Hofman A, Ikram MA, et al. (2013) Variant of TREM2 associated with the risk of Alzheimer's disease. N Engl J Med 368:107-116. CrossRef Medline

Kim KW, Vallon-Eberhard A, Zigmond E, Farache J, Shezen E, Shakhar G, Ludwig A, Lira SA, Jung S (2011) In vivo structure/function and expression analysis of the CX3C chemokine fractalkine. Blood 118:e156-e167. CrossRef Medline

Koenigsknecht-Talboo J, Meyer-Luehmann M, Parsadanian M, GarciaAlloza M, Finn MB, Hyman BT, Bacskai BJ, Holtzman DM (2008) Rapid microglial response around amyloid pathology after systemic anti-A $\beta$ antibody administration in PDAPP mice. J Neurosci 28:1415614164. CrossRef Medline

Kummer MP, Hermes M, Delekarte A, Hammerschmidt T, Kumar S, Terwel D, Walter J, Pape HC, König S, Roeber S, Jessen F, Klockgether T, Korte M, Heneka MT (2011) Nitration of tyrosine 10 critically enhances amyloid beta aggregation and plaque formation. Neuron 71:833-844. CrossRef Medline

Lambert JC, Heath S, Even G, Campion D, Sleegers K, Hiltunen M, Combarros O, Zelenika D, Bullido MJ, Tavernier B, Letenneur L, Bettens K, Berr C, Pasquier F, Fiévet N, Barberger-Gateau P, Engelborghs S, De Deyn P, Mateo I, Franck A, et al. (2009) Genome-wide association study identifies variants at CLU and CR1 associated with Alzheimer's disease. Nat Genet 41:1094-1099. CrossRef Medline

Lee S, Varvel NH, Konerth ME, Xu G, Cardona AE, Ransohoff RM, Lamb BT (2010) CX3CR1 deficiency alters microglial activation and reduces betaamyloid deposition in two Alzheimer's disease mouse models. Am J Pathol 177:2549-2562. CrossRef Medline

Li Y, Liu L, Barger SW, Griffin WS (2003) Interleukin-1 mediates pathological effects of microglia on tau phosphorylation and on synaptophysin synthesis in cortical neurons through a p38-MAPK pathway. J Neurosci 23:1605-1611. Medline

Lim GP, Yang F, Chu T, Chen P, Beech W, Teter B, Tran T, Ubeda O, Ashe KH, Frautschy SA, Cole GM (2000) Ibuprofen suppresses plaque pathology and inflammation in a mouse model for Alzheimer's disease. J Neurosci 20:5709-5714. Medline

Liu Z, Condello C, Schain A, Harb R, Grutzendler J (2010) CX3CR1 in microglia regulates brain amyloid deposition through selective protofibrillar amyloid-beta phagocytosis. J Neurosci 30:17091-17101. CrossRef Medline

Maier M, Peng Y, Jiang L, Seabrook TJ, Carroll MC, Lemere CA (2008) Complement $\mathrm{C} 3$ deficiency leads to accelerated amyloid beta plaque de- 
position and neurodegeneration and modulation of the microglia/macrophage phenotype in amyloid precursor protein transgenic mice. J Neurosci 28:6333-6341. CrossRef Medline

Michaud JP, Hallé M, Lampron A, Thériault P, Préfontaine P, Filali M, Tribout-Jover P, Lanteigne AM, Jodoin R, Cluff C, Brichard V, Palmantier R, Pilorget A, Larocque D, Rivest S (2013) Toll-like receptor 4 stimulation with the detoxified ligand monophosphoryl lipid A improves Alzheimer's disease-related pathology. Proc Natl Acad Sci U S A 110: 1941-1946. CrossRef Medline

Morganti JM, Nash KR, Grimmig BA, Ranjit S, Small B, Bickford PC, Gemma C (2012) The soluble isoform of CX3CL1 is necessary for neuroprotection in a mouse model of Parkinson's disease. J Neurosci 32:14592-14601. CrossRef Medline

Naj AC, Jun G, Beecham GW, Wang LS, Vardarajan BN, Buros J, Gallins PJ, Buxbaum JD, Jarvik GP, Crane PK, Larson EB, Bird TD, Boeve BF, GraffRadford NR, De Jager PL, Evans D, Schneider JA, Carrasquillo MM, Ertekin-Taner N, Younkin SG, et al. (2011) Common variants at MS4A4/MS4A6E, CD2AP, CD33 and EPHA1 are associated with lateonset Alzheimer's disease. Nat Genet 43:436-441. CrossRef Medline

Nash KR, Lee DC, Hunt JB Jr, Morganti JM, Selenica ML, Moran P, Reid P, Brownlow M, Guang-Yu Yang C, Savalia M, Gemma C, Bickford PC, Gordon MN, Morgan D (2013) Fractalkine overexpression suppresses tau pathology in a mouse model of tauopathy. Neurobiol Aging 34:15401548. CrossRef Medline

Njie EG, Boelen E, Stassen FR, Steinbusch HW, Borchelt DR, Streit WJ (2012) Ex vivo cultures of microglia from young and aged rodent brain reveal age-related changes in microglial function. Neurobiol Aging 33: 195.e1-195.e12. Medline

Paresce DM, Ghosh RN, Maxfield FR (1996) Microglial cells internalize aggregates of the Alzheimer's disease amyloid beta-protein via a scavenger receptor. Neuron 17:553-565. CrossRef Medline
Radde R, Bolmont T, Kaeser SA, Coomaraswamy J, Lindau D, Stoltze L, Calhoun ME, Jäggi F, Wolburg H, Gengler S, Haass C, Ghetti B, Czech C, Hölscher C, Mathews PM, Jucker M (2006) Abeta42-driven cerebral amyloidosis in transgenic mice reveals early and robust pathology. EMBO Rep 7:940-946. CrossRef Medline

Reed-Geaghan EG, Savage JC, Hise AG, Landreth GE (2009) CD14 and tolllike receptors 2 and 4 are required for fibrillar $\mathrm{A} \beta$-stimulated microglial activation. J Neurosci 29:11982-11992. CrossRef Medline

Streit WJ, Braak H, Xue QS, Bechmann I (2009) Dystrophic (senescent) rather than activated microglial cells are associated with tau pathology and likely precede neurodegeneration in Alzheimer's disease. Acta Neuropathol 118:475-485. CrossRef Medline

Suh J, Choi SH, Romano DM, Gannon MA, Lesinski AN, Kim DY, Tanzi RE (2013) ADAM10 missense mutations potentiate beta-amyloid accumulation by impairing prodomain chaperone function. Neuron 80:385-401. CrossRef Medline

Vom Berg J, Prokop S, Miller KR, Obst J, Kälin RE, Lopategui-Cabezas I, Wegner A, Mair F, Schipke CG, Peters O, Winter Y, Becher B, Heppner FL (2012) Inhibition of IL-12/IL-23 signaling reduces Alzheimer's diseaselike pathology and cognitive decline. Nat Med 18:1812-1819. CrossRef Medline

Wyss-Coray T, Lin C, Yan F, Yu GQ, Rohde M, McConlogue L, Masliah E, Mucke L (2001) TGF-betal promotes microglial amyloid-beta clearance and reduces plaque burden in transgenic mice. Nat Med 7:612-618. CrossRef Medline

Yamamoto M, Horiba M, Buescher JL, Huang D, Gendelman HE, Ransohoff RM, Ikezu T (2005) Overexpression of monocyte chemotactic protein1/CCL2 in beta-amyloid precursor protein transgenic mice show accelerated diffuse beta-amyloid deposition. Am J Pathol 166:1475-1485. CrossRef Medline 